\title{
Spodoptera frugiperda (Noctuidae) fed on transgenic maize can transfer Bt proteins
}

\section{to Podisus nigrispinus (Pentatomidae)}

\author{
Michael Willian Rocha de Souza ${ }^{*} \oplus$, Marcus Alvarenga Soares ${ }^{1 \oplus}$, José Eduardo Serrão ${ }^{2} \oplus$, Marinalva Martins dos Santos ${ }^{1 \oplus}$, Caique \\ Menezes de Abreu$^{1} \oplus$, Márcia Regina da Costa ${ }^{1}$
}

\begin{abstract}
'Universidade Federal dos Vales do Jequitinhonha e Mucuri - Depto. de Agronomia, Rod. MGT 367 - km 583, n 5000 39100-000 - Diamantina, MG - Brasil.

Universidade Federal de Viçosa - Depto. de Biologia Geral, Av. P.H. Rolfs, s/n - 36570-000 - Viçosa, MG - Brasil.

*Corresponding author <michaels|2011@hotmail.com>
\end{abstract}

Edited by: Alberto Soares Corrêa

Received February 17, 2021

Accepted April 05, 2021
ABSTRACT: An important concern with the use of genetically modified (GM) plants expressing Bacillus thuringiensis (Bt) insecticidal toxins is the deleterious effect on non-target organisms. The predatory stink bug Podisus nigrispinus (Dallas) (Hemiptera: Pentatomidae) is used in biological control programs and may be exposed to Bt toxins. This study evaluated the indirect effects of different Cry proteins on P. nigrispinus with the prey Spodoptera frugiperda (J.E. Smith, 1797) (Lepidoptera: Noctuidae), fed on simple or pyramided Bt maize genotypes. The experiment was carried out in a completely randomized design with three treatments: i) Isohybrid (not Bt), ii) Hercule ${ }^{\circledR}$ (transgenic maize encoding Cry1F protein) and iii) PowerCore ${ }^{\circledR}$ (pyramidal transgenic maize encoding the Cry1F, Cry1A.105, and Cry2Ab2 proteins), which were used to feed $S$. frugiperda for $48 \mathrm{~h}$. The caterpillars were used as prey by $P$. nigrispinus females. We evaluated the presence of Cry proteins, consumed prey biomass (predation), oviposition period, number of postures, number of eggs, number of eggs per posture, number of nymphs, egg viability, embryonic period, female longevity and development, and survival rates of immature. The results show that different Cry proteins move through the food chain of $P$. nigrispinus and provide evidence that the ingestion of three different proteins does not lead to unexpected synergistic effects. However, Cry toxins promoted histopathological changes in midgut cells of P. nigrispinus.

Keywords: Bacillus thuringiensis, biological control, non-target effect, predator

\section{Introduction}

Genetically modified (GM) crops that contain genes introduced by genetic engineering to control insects express pesticidal proteins (Cry) from the bacterium Bacillus thuringiensis $(\mathrm{Bt})$ that may have insecticidal action on insects of the orders Lepidoptera, Coleoptera, Hymenoptera, and Diptera (Abbas, 2018). Because of their high control efficacy and ease use, Bt crops have increased rapidly (Huang, 2020).

Nonetheless, Cry proteins can be transferred directly or indirectly to other non-target arthropods insensitive to Cry toxins or natural enemies, particularly predators and parasitoids (Dutra et al., 2012). Knowledge of the possible effects of Cry toxins on non-target organisms supports the risk assessment that precedes the commercial cultivation of any GM plant, especially because these toxins move through different trophic levels (Meissle and Romeis, 2018).

In modern crops, several Cry proteins and others have been stacked or pyramided, either by simultaneous multiple gene transfer or by conventional breeding methods of plants containing individual transgenes (Svobodová et al., 2017b). Different Cry proteins in stacked or pyramidal Bt plants may interact synergistically and lead to unexpected effects on non-target species (Hilbeck and Otto, 2015).

The fall armyworm, Spodoptera frugiperda (J.E. Smith, 1797) (Lepidoptera: Noctuidae), is an agricultural pest original from tropical and subtropical regions and causes significant losses in various crops (e.g. maize, cotton, and soybean) (Tian et al., 2014). The widespread use of Bt results in the rapid occurrence of resistance of $S$. frugiperda to Cry1F maize (TC 1507) affecting field control of this pest in Argentina, Brazil, Puerto Rico, and the United States (Huang, 2020).

Podisus nigrispinus (Dallas, 1851) (Hemiptera: Pentatomidae) naturally occurs in a variety of agroecosystems and is the most common species of Asopinae in Brazil, also used for biological control in agricultural and forestry systems (Zanuncio et al., 2016). In addition to feeding on prey, P. nigrispinus has the habit of sucking parts of plants to obtain water and minerals (Torres et al., 2010; Vieira et al., 2018), such behavior increases the risk of contact with Cry toxins when exposed to Bt plants. For these predatory insects, exposure to Cry proteins can cause physiological damage, affecting behavior, development, and longevity (Cunha et al., 2013; Jesus et al., 2014; Carvalho et al., 2018; Marques et al., 2018).

This study evaluated the flow of different Cry proteins in $P$. nigrispinus fed on $S$. frugiperda previously fed on simple or pyramided Bt maize genotypes, as well as the developmental, predatory, and reproductive ability of the predator. In addition, we assessed toxicity and histopathological changes mediated by these Cry proteins in the midgut of $P$. nigrispinus. 


\section{Materials and Methods}

\section{Plants}

The hybrids, Isohybrid (Dow AgroSciences, São Paulo, $\mathrm{SP}$, Brazil), non-Bt isogenic maize of the same genetic background used as control, Herculex ${ }^{\circledR}$ (TC1507, Dow AgroSciences LLC, Indianapolis, IN, USA), transgenic maize coding for protein Cry $1 \mathrm{~F}$ and, PowerCore ${ }^{\circledR}$ (MON $89034 \times$ TC1507 $\times$ NK603, Monsanto Technology LLC and Dow AgroSciences LLC, Indianapolis, IN, USA), transgenic pyramidal maize coding for proteins Cry1F, Cry1A.105, and Cry2Ab2, were used in this experiment. Maize was kept in a greenhouse in $8 \mathrm{~L}$ pots. The cultivation was carried out according to the recommendations for Brazil, without the application of insecticides, fungicides and, herbicides.

\section{Insects}

Eggs of Spodoptera frugiperda were obtained from massrearing conditions in Diamantina, Minas Gerais State, Brazil. The insects were kept at $25 \pm 2{ }^{\circ} \mathrm{C}, 75 \pm 5 \% \mathrm{RH}$ and a 12:12 (light: dark) photoperiod. After hatching, caterpillars were fed on artificial diet (Greene et al., 1976).

Adults of Podisus nigrispinus were obtained from mass-rearing kept at $25 \pm 2{ }^{\circ} \mathrm{C}, 75 \pm 5 \% \mathrm{RH}$ and a 12:12 (light: dark) photoperiod. These insects were fed on Tenebrio molitor (Linnaeus, 1758) (Coleoptera: Tenebrionidae) pupae and Eucalyptus grandis (Myrtaceae) leaves ad libitum (Neves et al., 2010). Water was supplied in an anesthesia tube type fixed at the cover of the plastic pot $(500 \mathrm{~mL})$ and with its extremity closed with cotton.

\section{Bioassays}

Bioassays were carried out in laboratory at $25 \pm 2{ }^{\circ} \mathrm{C}$, $75 \pm 5 \% \mathrm{RH}$ and a 12:12 (light: dark) photoperiod. The experiment was carried out in a completely randomized design with three maize genotypes: i) Isohybrid, ii) Herculex $^{\circledR}$ and iii) PowerCore ${ }^{\circledR}$. We used 14 replications, each replicate included a $P$. nigrispinus female, fed on $S$. frugiperda, that consumed Bt or non-Bt maize leaves.

Caterpillars of $S$. frugiperda, 10 days old, were individualized in transparent plastic pots $(500 \mathrm{~mL})$ and fed ad libitum with Isohybrid, Herculex ${ }^{\circledR}$, or PowerCore ${ }^{\circledR}$ maize leaves at the vegetative stage V3 for $48 \mathrm{~h}$ (the leaves were renewed every $24 \mathrm{~h}$ ). The use of caterpillars at 10 days of age was determined by preliminary tests to simulate certain resistance to Cry proteins. The caterpillars were weighed before and after feeding on each evaluated maize genotype.

Females of Podisus nigrispinus ( 3 days old) were individualized and fed daily for $3 \mathrm{~d}$ with one $S$. frugiperda fed with each maize genotype. The amount of food supplied to the female of $P$. nigrispinus was sufficient and determined by preliminary tests, where the prey was not fully consumed by the predator during the $24 \mathrm{~h}$. The biomass consumed (predation) by $P$. nigrispinus was determined daily. For this, $S$. frugiperda was weighed before and after $24 \mathrm{~h}$ of contact with the predator. Caterpillars with tegument lesions, lack of mobility, or partially or fully sucked body contents were considered predated.

Females Podisus nigrispinus were individualized after predation of $S$. frugiperda with a male in transparent plastic pots $(500 \mathrm{~mL})$ and fed on T. molitor larvae and pupae. From these adults, the following reproduction data were obtained: oviposition period, number of oviposition events, number of eggs, number of eggs per oviposition, number of nymphs, egg viability, embryonic period, and longevity of females. Eggs were collected daily and placed in Petri dishes $(9 \mathrm{~cm}$ diameter) to determine incubation period and viability. Each Petri dish contained a moistened cotton ball attached to the lid to prevent dehydration of eggs.

Ten nymphs per treatment (from different egg masses and emerged on the same day), after reaching the second instar, were collected and individualized in transparent plastic containers. Nymph development was observed until adult emergence to evaluate the duration of nymphal instars.

Data on biomass gain, biomass consumed, reproduction, and development were submitted to analysis of variance (ANOVA) and the means were compared by the Tukey test at $5 \%$ significance level with the statistical program SISVAR. For ANOVA, original data on the percentage of egg viability, number of eggs, and nymphs were transformed using arcsine $\left(\chi^{0.5}\right)$ to meet the assumptions of normality.

\section{Cry Detection}

To evaluate the presence of Cry $1 \mathrm{~F}$ protein and Cry1A.105 and Cry2Ab2 proteins in maize plants, $S$. frugiperda and, $P$. nigrispinus, we used the Envirologix QuickStix ${ }^{\mathrm{TM}}$ kit for Cry1F and Cry2A. Three samples with leaf tissue, $S$. frugiperda or $P$. nigrispinus were used for the detection of Cry proteins in Herculex ${ }^{\circledR}$ and PowerCore ${ }^{\circledR}$ genotypes and four samples for Isohybrid (two Envirologix QuickStix ${ }^{\mathrm{TM}}$ strips for Cry $1 \mathrm{~F}$ and two for Cry $1 \mathrm{~A} .105$ and Cry2Ab2 were used in each sample).

In each Eppendorf tube containing the samples, $0.5 \mathrm{~mL}$ of the extraction buffer was added then the samples were macerated with the disposable pestle. The insects were macerated completely (one $S$. frugiperda or $P$. nigrispinus) and one disc ( $1 \mathrm{~cm}$ in diameter) of maize tissue was ground by rotating the pestle against the sides of the tube with twisting motions. The Eppendorfs were closed and shaken carefully for $30 \mathrm{sec}$. Subsequently, the tubes were placed in a holder and an Envirologix QuickStix $^{\mathrm{TM}}$ Cry $1 \mathrm{~F}$ strip for Herculex ${ }^{\circledR}$ maize samples and an Envirologix QuickStix ${ }^{\mathrm{TM}}$ Cry2A strip for PowerCore ${ }^{\circledR}$ maize were added. The strips were kept inside each sample for $10 \mathrm{~min}$ to interpret the results. 
In samples with the presence of Cry1F or Cry1A.105 and Cry2Ab2, a second line (test line) was detected in the region between the control line and the lower end of the strip. For negative samples, the strip only developed the control line.

\section{Histological Analysis}

Nine $P$. nigrispinus females per treatment, after predation of $S$. frugiperda, were cryoanesthetized at $-4{ }^{\circ} \mathrm{C}$ and dissected under a stereomicroscope for midgut removal, which was subsequently transferred to aqueous $2.5 \%$ glutaraldehyde for $24 \mathrm{~h}$. The samples were dehydrated in a graded ethanol series $(70 \%, 80 \%, 90 \%$, and $95 \%)$ for $10 \mathrm{~min}$ and embedded in Historesin (Leica Biosystems Nussloch $\mathrm{GmbH}$, Wetzlar, Germany) for $24 \mathrm{~h}$. Slices $3 \mu \mathrm{m}$ thick were obtained on microtome, stained with hematoxylin and eosin, and analyzed under a light microscope. The images (photomicrographs) were submitted to Adobe Photoshop software for contrast adjustment, white balance, balance, and scaling. Subsequently, the boards were made from photomicrographs using Corel DRAW 12 (Corel Incorporated) software.

\section{Results}

The QuickStix ${ }^{\mathrm{TM}}$ immunochromatographic strip test for Cry $1 \mathrm{~F}$ and Cry2A was negative for maize leaf, $S$.

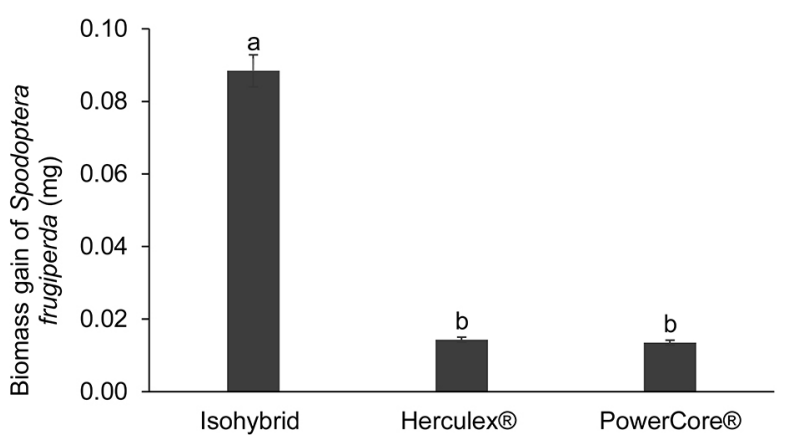

Figure 1 - Biomass gain of Spodoptera frugiperda $(\mathrm{mg})$ after 48 hours feeding on Isohybrid, Herculex ${ }^{\circledR}$ or PowerCore ${ }^{\circledR}$ maize genotypes. Means followed by the same letter do not differ from each other at $5 \%$ significance by the Tukey test. frugiperda, and $P$. nigrispinus samples in the Isohybrid treatment. The development of the control line indicates that the strip worked correctly. The results of QuickStix ${ }^{\mathrm{TM}}$ strips with Herculex ${ }^{\circledR}$ and PowerCore ${ }^{\circledR}$ were positive for maize leaves, $S$. frugiperda fed on $\mathrm{Bt}$ maize, and samples with the predator $P$. nigrispinus that predated $S$. frugiperda.

Biomass gain of $S$. frugiperda without exposure to Cry protein (Isohybrid) is approximately nine-fold higher than in caterpillars fed on Herculex ${ }^{\circledR}$ or PowerCore ${ }^{\circledR}$ maize leaves for $48 \mathrm{~h}$ (Figure 1).

The consumed biomass of $S$. frugiperda by $P$. nigrispinus was higher in Isohybrid treatment $\mid 0.061$ $\pm 0.03 \mathrm{mg}$ ) whereas Herculex ${ }^{\circledR}(0.031 \pm 0.01 \mathrm{mg})$ and PowerCore $^{\circledR}(0.039 \pm 0.01 \mathrm{mg})$ did not differ by the Tukey test at $5 \%$ significance (Figure 2).

The results for reproduction parameters were similar between the treatments with the oviposition period (17.16 \pm 8.60 to $24.33 \pm 9.83$ days), number of oviposition events $(15.25 \pm 6.45$ to $21.41 \pm 8.36)$, number of eggs $(219.66 \pm 153.28$ to $339.75 \pm 195.83)$, number of eggs per oviposition $(12.28 \pm 3.90$ to $14.67 \pm$ $4.78)$, number of nymphs (187.50 \pm 144.21 to $289.58 \pm$ 200.30), egg viability $(76.05 \pm 27.94$ to $84.15 \pm 7.78 \%)$, embryonic period $(4.29 \pm 1.36$ to $4.77 \pm 0.12)$, and longevity of females $(25.33 \pm 9.51$ to $33.08 \pm 10.84$ days $)$ (Table 1).

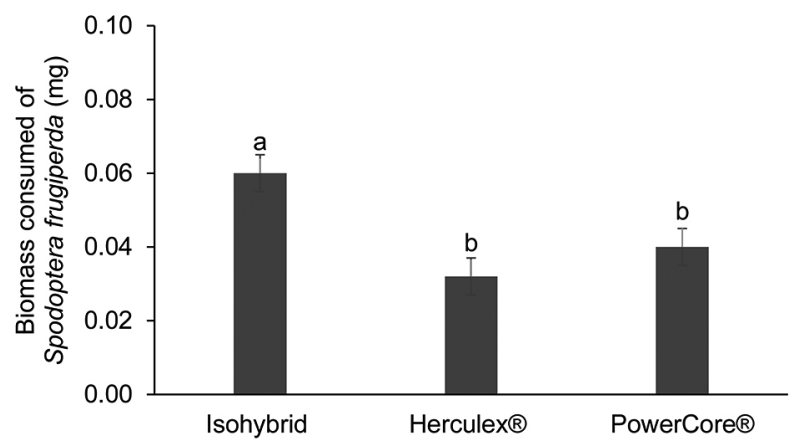

Figure 2 - Biomass consumed of Spodoptera frugiperda (mg), after 48 hours feeding on Isohybrid, Herculex ${ }^{\circledR}$ or PowerCore ${ }^{\circledR}$ maize genotypes, by the predator Podisus nigrispinus. Means followed by the same letter do not differ from each other at $5 \%$ significance by the Tukey test.

Table 1 - Reproduction parameters (mean \pm standard error) of Podisus nigrispinus (Hemiptera: Pentatomidae) after predation of Spodoptera frugiperda (Lepidoptera: Noctuidae) fed Isohybrid, Herculex ${ }^{\circledR}$ or PowerCore ${ }^{\circledR}$ maize genotypes. Diamantina, Minas Gerais, Brazil.

\begin{tabular}{lccc}
\hline Parameters & Isohybrid & Herculex $^{\circledR}$ & PowerCore $^{\circledR}$ \\
\hline Oviposition (days) & $18.41 \pm 7.49 \mathrm{a}$ & $24.33 \pm 9.83 \mathrm{a}$ & $17.16 \pm 8.60 \mathrm{a}$ \\
Number of postures & $17.25 \pm 8.40 \mathrm{a}$ & $21.41 \pm 8.36 \mathrm{a}$ & $15.25 \pm 6.45 \mathrm{a}$ \\
$\mathrm{N}$. of eggs & $222.00 \pm 126.34 \mathrm{a}$ & $339.75 \pm 195.83 \mathrm{a}$ & $219.66 \pm 153.28 \mathrm{a}$ \\
$\mathrm{N}$. of eggs per posture & $12.28 \pm 3.90 \mathrm{a}$ & $14.67 \pm 4.78 \mathrm{a}$ & $13.84 \pm 4.41 \mathrm{a}$ \\
$\mathrm{N}$. of nymphs & $187.91 \pm 114.74 \mathrm{a}$ & $289.58 \pm 200.30 \mathrm{a}$ & $187.50 \pm 144.21 \mathrm{a}$ \\
Egg viability (\%) & $81.73 \pm 10.00 \mathrm{a}$ & $76.05 \pm 27.94 \mathrm{a}$ & $84.15 \pm 7.78 \mathrm{a}$ \\
Embryo period (days) & $4.77 \pm 0.12 \mathrm{a}$ & $4.29 \pm 1.36 \mathrm{a}$ & $4.74 \pm 0.13 \mathrm{a}$ \\
Female longevity (days) & $27.91 \pm 9.57 \mathrm{a}$ & $33.08 \pm 10.84 \mathrm{a}$ & $25.33 \pm 9.51 \mathrm{a}$ \\
\hline
\end{tabular}

Means followed by the same letter in the line do not differ between them at $5 \%$ of significance by the Tukey test. 
There were no differences in the duration of the nymphal period of $P$. nigrispinus, with values ranging from $2.38 \pm 0.18$ to $2.70 \pm 0.15,3.40 \pm 0.16$ to 3.86 $\pm 0.26,2.50 \pm 0.22$ to $2.88 \pm 0.35$ and, $3.29 \pm 0.18$ to $4.00 \pm 0.38$ days, for I, II, III and IV instar respectively. However, the $5^{\text {th }}$ instar nymph was $2 \mathrm{~d}$ longer when predators fed on $S$. frugiperda from Isohybrid genotype and $5 \mathrm{~d}$ for Herculex ${ }^{\circledR}$ and PowerCore ${ }^{\circledR}$ (Table 2).

The midgut of $P$. nigrispinus females not exposed to Cry proteins had the epithelium with a single layer of columnar cells with a well-developed apical portion brush border and the cytoplasm with some vacuoles and secretory vesicles (Figures $3 \mathrm{~A}, 3 \mathrm{~B}$ and $3 \mathrm{C}$ ).

Histopathological changes were found in the midgut of $P$. nigrispinus after exposure to Cry $1 \mathrm{~F}$, Cry1A.105 and Cry2Ab2 proteins. The epithelium was irregular with signs of degeneration characterized by the release of cell debris containing pyknotic nucleus into the gut lumen (Figures 3D, 3E, 3G, and 3H).

After exposure to Cry proteins, the midgut epithelium showed apical cell protrusions, increase in the number of secretory vesicles and vacuoles of varying sizes in the epithelial cytoplasm, located in the cellular apical region, where the cytoplasmic content protrudes into the midgut lumen (Figures 3E, 3F, 3G and $3 \mathrm{I})$.

\section{Discussion}

In Brazil, Bt-resistant populations of $S$. frugiperda has been selected mainly due to the rapid dispersion of $\mathrm{Bt}$ maize plantations, poor implementation, and adoption of resistance management practices, and low refuge compliance (Farias et al., 2014; Moscardini et al., 2020). Thus, implementing effective insect resistance management (IRM) strategies is essential to ensure the success of the Bt crop technology (Yang et al., 2017).

Table 2 - Duration in days (mean \pm standard error) of Podisus nigrispinus (Hemiptera: Pentatomidae) instars after predation on Spodoptera frugiperda (Lepidoptera: Noctuidae) fed with Isohybrid, Herculex ${ }^{\circledR}$ or PowerCore ${ }^{\circledR}$ maize genotypes. Diamantina, Minas Gerais, Brazil.

\begin{tabular}{lccc}
\hline \multirow{3}{*}{ Instar } & \multicolumn{3}{c}{ Duration (days) } \\
\cline { 2 - 4 } I & Isohybrid & Herculex $^{\circledR}$ & PowerCore $^{\circledR}$ \\
II & $2.50 \pm 0.17 \mathrm{a}$ & $2.70 \pm 0.15 \mathrm{a}$ & $2.38 \pm 0.18 \mathrm{a}$ \\
III & $3.40 \pm 0.16 \mathrm{a}$ & $3.86 \pm 0.26 \mathrm{a}$ & $3.63 \pm 0.18 \mathrm{a}$ \\
IV & $2.50 \pm 0.22 \mathrm{a}$ & $2.86 \pm 0.14 \mathrm{a}$ & $2.88 \pm 0.35 \mathrm{a}$ \\
V & $3.50 \pm 0.22 \mathrm{a}$ & $4.00 \pm 0.38 \mathrm{a}$ & $3.29 \pm 0.18 \mathrm{a}$ \\
Nymphal period & $19.11 \pm 1.11 \mathrm{a}$ & $18.43 \pm 0.75 \mathrm{a}$ & $17.16 \pm 0.48 \mathrm{a}$ \\
\hline
\end{tabular}

Means followed by the same letter in the line do not differ between them at $5 \%$ of significance by the Tukey test.

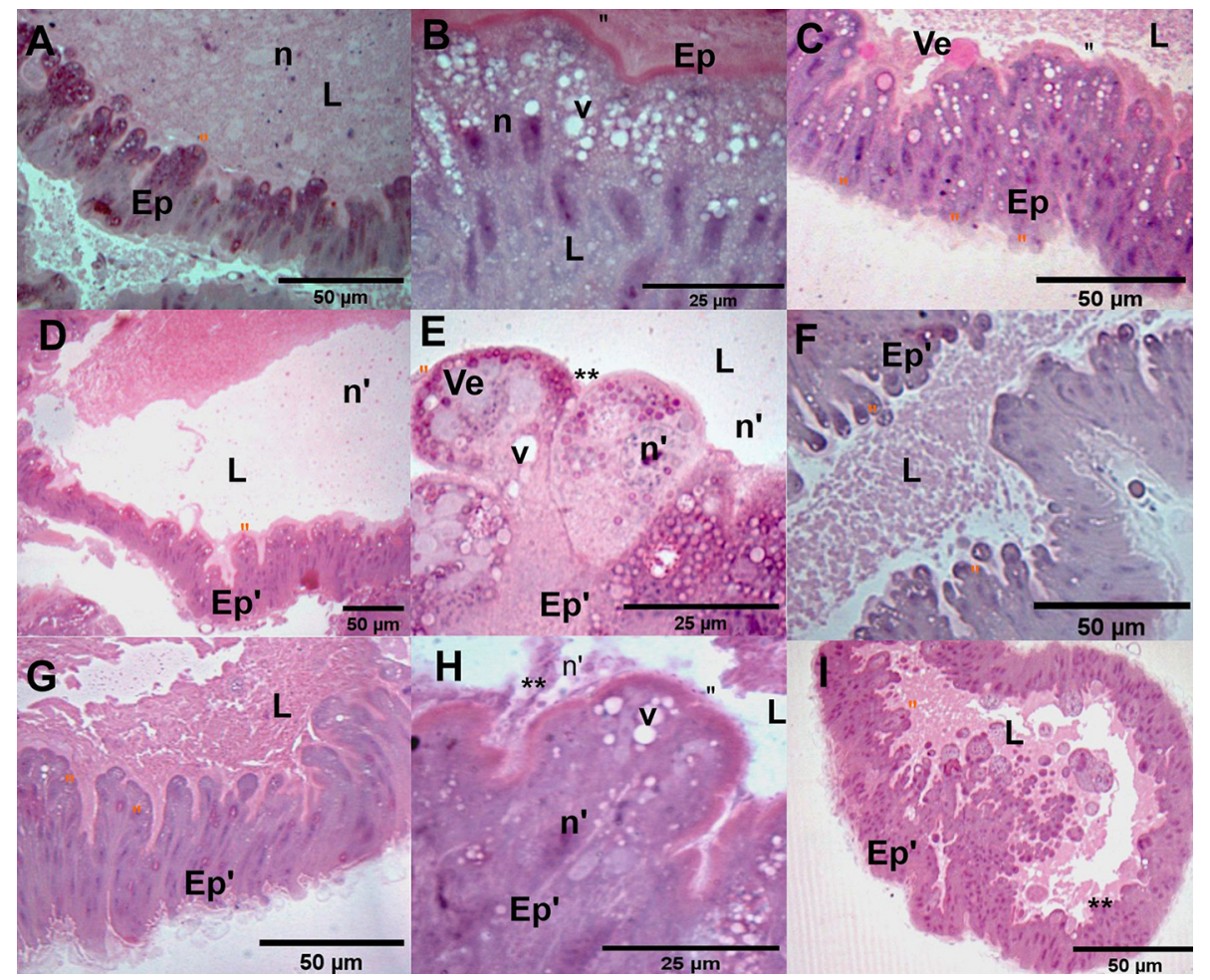

Figure 3 - Histological sections of the midgut of Podisus nigrispinus (Hemiptera: Pentatomidae) after predating Spodoptera frugiperda (Lepidoptera: Noctuidae) fed on Isohybrid (A, B and C), Herculex ${ }^{\circledR}\left(D, E\right.$ and $F$ ) or PowerCore ${ }^{\circledR}(G, H$ and I) maize. Anterior (A, D and G), middle $(B, E$ and $H)$ and posterior ( $C, F$, and I) midgut regions showing effects of proteins Cry1F, Cry1A.105, and Cry2Ab2 with high number of vacuoles $(v)$, vesicles (Ve), nuclei $(n)$ with condensed chromatin $(n ')$, cellular fragments $\left(^{* *}\right)$ released into the lumen $(L)$ and epithelium (Ep) with irregular aspect (Ep') (D, E, F, G, H and I), with columnar cells (orange ") and striated border (black " ). 
Therefore, target insect resistance may be delayed with the use of biological control (Pereira, 2014), including the predator $P$. nigrispinus.

The negative result of the immunochromatographic test in the Isohybrid treatment confirms that this genotype does not express Bt proteins. Positive results in Herculex ${ }^{\circledR}$ and PowerCore ${ }^{\circledR}$ treatments in leaf samples, $S$. frugiperda and $P$. nigrispinus demonstrate the transfer of different plant Cry proteins to herbivores and predators. Caterpillars that fed on maize leaves containing Cry $1 \mathrm{~F}$ or Cry $1 \mathrm{~A} .105$ and Cry2Ab2 proteins, even for $48 \mathrm{~h}$, accumulated the proteins and transferred them to $P$. nigrispinus predator. The flow of Cry proteins in the trophic level has been reported in many insects (Dutra et al., 2012; Yu et al., 2014; Marques et al., 2018; Souza et al., 2018). The amount of Bt protein ingested may differ according to the herbivorous species in terms of time and place of toxin expression in the plant, the herbivorous food ecology, as well as the amount of plant material ingested (Devos et al., 2012). However, Cry proteins are diluted from the lowest to the highest trophic levels due to excretion and digestion (Svobodová et al., 2017b; Li et al., 2017).

Predators are exposed to Bt protein concentrations ranging from $5 \%$ to $50 \%$ of average leaf concentrations when feeding on herbivores. Predators Adalia bipunctata (Linnaeus, 1758) (Coleoptera: Coccinellidae), Chrysoperla carnea (Stephens, 1836) (Neuroptera: Chrysopidae), and Harmonia axyridis (Palias, 1733) (Coleoptera: Coccinellidae) obtain $1 \%$ to $30 \%$ of the Bt protein from the prey Spodoptera littoralis (Boisduval, 1833) (Lepidoptera: Noctuidae), demonstrating that these proteins are diluted at higher trophic levels (Meissle and Romeis, 2018). Podisus nigrispinus is a zoophytophgous predator because it also feeds on plant sap to obtain water and additional nutrients (Peluzio et al., 2018; Vieira et al., 2018) thus acquiring a higher concentrations of Bt proteins than zoophagous predators.

The physiological mechanism of $\mathrm{Bt}$ protein sequestration is poorly known. However, after the protein is ingested, it crosses the peritrophic matrix bind to the ABC-membrane transporter of midgut cells disrupting the epithelium (Mitsuhashi and Miyamoto, 2020). Therefore, some Cry toxins may cross the midgut barrier to be stored in the fat body (Telfer and Kunkel, 1991; Locke and Collins, 1968). Protein uptake from the hemolymph to the fat body seems to occur by endocytosis (Locke and Collins, 1966; Tojo et al., 1978). This may occur in $S$. frugiperda allowing the movement of different Cry proteins of the plant to higher trophic levels.

The higher biomass gains of $S$. frugiperda fed on Isohybrid maize than on transgenic genotypes suggest that Bt toxins may decrease consumption of plant tissues due to gut paralysis (Sikorowski and Lawrence, 1997; Prütz and Dettner, 2004). Low weight has been reported in herbivores due to slow feed rate in Bt plants (De Sousa Ramalho et al., 2011) as well as low digestion rate
(Razze et al., 2011). Spodoptera frugiperda fed on Cry $1 \mathrm{Ab}$ maize compared to those fed on the same non-Bt hybrid had a 20-fold reduction in their biomass (Mendes et al., 2011). The amount of food consumed by Helicoverpa zea (Boddie, 1850) (Lepidoptera: Noctuidae), S. frugiperda and Spodoptera exigua (Hübner) (Lepidoptera: Noctuidae) in non-Bt cotton cultivar (DPL50) was higher than in Bt cultivars. Moreover, plants expressing two Bt toxins have higher sublethal effects on caterpillar than single toxin-expressing cultivar (Stewart et al., 2001). In this study, no statistical differences were observed between genotypes with more or less Bt proteins.

The lower predation of $P$. nigrispinus in prey fed on Bt maize may be due to the low caterpillar biomass and nutritional deficiency. Low biomass accumulation may be an indicator of lower nutritional quality (Pereira, 2014). Cotton expressing Cry1Ac (cultivar DP 404 BG Bollgard; Monsanto, Saint Louis, MO, USA) negatively affects $S$. frugiperda nutritional indexes, such as relative growth rate, relative consumption rate, relative metabolic rate, approximate digestibility, metabolic cost, ingested feed conversion efficiency, and digested feed conversion efficiency (De Sousa Ramalho et al., 2011). Lower consumption of genetically modified maize genotypes can also affect the amount of $\mathrm{N}$ acquired by insects. The need for $\mathrm{N}$ from the plant for phytophagous insects is evident, due to the central role that $\mathrm{N}$ plays in metabolic processes, cell structure, and genetic code (Pizzamiglio, 1991). Dicyphus hesperus (Knight, 1943) (Hemiptera: Miridae) feeds more on prey with high $\mathrm{N}$ concentrations than those with low concentrations (Vankosky and Vanlaerhoven, 2015). Thus, nutritional deficiency, such as low $\mathrm{N}$ in Herculex ${ }^{\circledR}$ or PowerCore ${ }^{\circledR}$ maize-fed prey, may discourage $P$. nigrispinus predation.

Spodoptera frugiperda without exposure to Cry protein (Isohybrid) had higher biomass for predation, which was quickly consumed, unlike caterpillars exposed to the protein. This study did not evaluate the number of preys consumed; however, this number is possibly higher in prey in contact with transgenic crops due to reduced nutritional value. Predation of $P$. nigrispinus nymphs and adults was higher in $S$. frugiperda fed on leaves of the transgenic cotton $\mathrm{NuOpal}^{\circledR}$ (Jesus et al., 2014). The predator $H$. axyridis has preference for older Bt-fed $S$. frugiperda, when weight differences between caterpillars exposed or not to Bt increased (Svobodová et al., 2017a). Harmonia axyridis likely compensated the reduction in Bt-fed $S$. frugiperda biomass by increasing the number of caterpillars consumed (Lawo et al., 2010). This partly explains the indirect effects found in this work of lower biomass consumption in $S$. frugiperda fed Herculex ${ }^{\circledR}$ or PowerCore ${ }^{\circledR}$ maize when the same number of preys was offered to predators.

Reproduction parameters of $P$. nigrispinus followed 3-day feeding on Bt-fed prey was not significantly affected. Podisus nigrispinus exposed to Cry proteins through different food sources have similar number of eggs per female, number of eggs per day, fecundity, 
and fertility (Carvalho et al., 2012), nymph survival, duration of pre-oviposition, oviposition, and adult longevity (Santana et al., 2017). On the other hand, the oviposition period and the number of eggs per postures of $P$. nigrispinus change when predating T. molitor larvae fed on wheat bran containing different $B$. thuringiensis (Agree ${ }^{\circledR}$ ) concentrations (Carvalho et al., 2018). Despite the differences found in oviposition periods and number of eggs, these values were higher than those found when the predator was fed on Diatraea saccharalis (Fabricius, 1794) (Lepidoptera: Crambidae) (Vacari et al., 2007) and with the alternative prey $T$. molitor (Zanuncio et al., 1996; Bortoli et al., 2011), respectively.

The prolongation of the $5^{\text {th }}$ instar nymph of $P$. nigrispinus fed on prey from Isohybrid genotype may be related to several factors, such as food quality (Zanuncio et al., 2001; Oliveira et al., 2011); however, a longer duration of final instars is common for these natural enemies (Zanuncio et al., 2001; Oliveira et al., 2004). Cry1A, Cry2Ab, and Cry1F proteins do not affect larval survival and developmental time of Chrysoperla rufilabris (Burmeister, 1839) (Neuroptera: Chrysopidae) (Tian et al., 2013). On the other hand, the duration of the $3^{\text {rd }}$ instar of $P$. nigrispinus ranged from 4.90 to 3.23 days when the prey was fed on $\mathrm{NuOpal}^{\circledR}$ and non-transgenic DeltaOpal ${ }^{\circledR}$ cotton, respectively (Jesus et al., 2014). The nymphal development of this predator was four days longer when they fed on Plutella xylostella (Linnaeus, 1758) (Lepidoptera: Plutellidae) treated with Bt HD-1 bioinsecticide, probably due to the poor nutritional quality of prey. The nymphal period was $21.1 ; 18.6$ and 17.1 days for $\mathrm{HD}-1$, Agree $^{\circledR}$ and control, respectively (Magalhães et al., 2015).

Although Cry1F, Cry1A.105, and Cry2Ab2 have non-lethal effects for $P$. nigrispinus after predation of $S$. frugiperda fed on Bt maize genotypes, some histopathological effects occur in the digestive tract of this predator. Oliveira et al. (2016) suggest that $P$. nigrispinus digestive enzymes do not fully degrade the Cry1Ac toxin. Insect susceptibility to Bt protein varies with time and site of toxin expression in the plant, herbivorous food ecology, amount of plant material ingested (Devos et al., 2012), and the presence of specific receptors on microvilli of midgut cells (Bravo et al., 2007; Castro et al., 2017; Javed et al., 2019).

Typical features of cellular degeneration, such as irregularly shaped epithelium, nuclear chromatin condensation, apical cell protrusion, and release of cell fragments into the midgut lumen of $P$. nigrispinus show possible side effects of Bt toxins. These morphological changes may indicate a decrease in the digestive capacity of insects, as reported in Helicoverpa armigera (Hübner, 1805) (Lepidoptera: Noctuidae) and Anticarsia gemmatalis (Hübner, 1818) (Lepidoptera: Noctuidae) in response to the toxic effect of Bt (Barbeta et al., 2008; Castro et al., 2019).

Cell fragments released into the midgut lumen of $P$. nigrispinus after predation of $S$. frugiperda fed on transgenic maize implies cytotoxic effect causing apoptosis, a morphological pattern of programmed cell death (Ihara et al., 1998). Discarding cells by cell death (Santos et al., 2015) might be a response to damages to midgut epithelial cells after Bt ingestion. Infections, mutations, presence of viruses, toxic aggressions, such as insecticides or herbicides, thermal shock, ionizing radiation, among others are stimuli described as triggers of midgut cell death (Gonçalves et al., 2013; Daniel et al., 2014; Gonçalves et al., 2016). Despite the importance of apoptosis to eliminate damaged or infected cells that may affect their normal function, excessive apoptosis can impair tissue function (Portt et al., 2011; Clapp et al., 2012), affecting important digestion processes and consequently predation and survival.

Daily dietary intake of approximately $23 \pm 0.70 \mathrm{ng}$ $\mathrm{g}^{-1}$ Cry1Ac by wet weight of leaves and expressed by Bt cotton induces small ultrastructural changes in predator $P$. nigrispinus granulocytes and plasmatocytes (Cunha et al., 2013). Exposure to Bt proteins also causes microvilli elongation, increase the presence of spherocrystals and granules of different electron densities, as well as changes in the pattern of glycogen, lipid, and calcium distribution of these cells in the midgut (Cunha et al., 2012).

\section{Conclusion}

Conserving natural enemies to improve pest control is a challenge in integrated pest management programs. Thus, the use of Bt plants needs to be evaluated due to its possible adverse effects on non-target organisms. Our results show that different Cry proteins move through the $P$. nigrispinus food chain. Besides, the study provides evidence that exposure period of $P$. nigrispinus females to $S$. frugiperda that consumed maize leaves expressing Bt toxins has no synergistic effects on the non-target species investigated. However, the Cry1F, Cry1A.105, and $\mathrm{Cry} 2 \mathrm{Ab} 2$ toxins consumed by $S$. frugiperda cause histopathological changes in the midgut of $P$. nigrispinus ( $3^{\text {rd }}$ trophic level), which may compromise the predator fitness.

\section{Acknowledgments}

To "Minas Gerais State Agency for Research and Development (FAPEMIG)" - Finance Code 5.310/15 and "Coordination for the Improvement of Higher Level Personnel (CAPES)" - Finance Code 001, for financial support.

\section{Authors' Contributions}

Conceptualization: Souza, M.W.R.; Soares, M.A.; Costa, M.R. Data acquisition: Serrão, J.E.; Abreu, C.M.; Santos, M.M. Data analysis: Souza, M.W.R.; Serrão, J.E. Design of methodology: Souza, M.W.R.; Soares, M.A.; Costa, M.R. Writing and editing: Souza, M.W.R.; Abreu, C.M.; Soares, M.A.; Costa, M.R. 


\section{References}

Abbas, M.S.T. 2018. Genetically engineered (modified) crops (Bacillus thuringiensis crops) and the world controversy on their safety. Egyptian Journal of Biological Pest Control 28: 52.

Barbeta, B.L.; Marshall, A.T.; Gillon, A.D.; Craik, D J.; Anderson, M.A. 2008. Plant cyclotides disrupt epithelial cells in the midgut of lepidopteran larvae. Proceedings of the National Academy of Sciences 105: 1221-1225.

Bortoli, S.A.; Otuka, A.K.; Vacari, A.M.; Martins, M.I.; Volpe, H.X. 2011. Comparative biology and production costs of Podisus nigrispinus (Hemiptera: Pentatomidae) when fed different types of prey. Biological Control 58: 127-132.

Carvalho, G.A.S.D.; Martins, D.J.; Brito, I.M.C.D.; Assis Júnior, S.L.D.; Soares, M.A.; Laia, M.L.D.; Valicente, F.H. 2018. Can Bacillus thuringiensis affect the biological variables of natural enemies of Lepidoptera? Arquivos do Instituto Biológico 85: e0052018.

Carvalho, V.F.P.; Vacari, A.M.; Pomari, A.F.; Bortoli, C.P.; Ramalho, D.G.; Bortoli, S.A. 2012. Interaction between the predator Podisus nigrispinus (Hemiptera: Pentatomidae) and the entomopathogenic bacteria Bacillus thuringiensis. Environmental Entomology 41: 1454-1461.

Castro, B.M.D.C.; Martinez, L.C.; Barbosa, S.G.; Serrão, J.E.; Wilcken, C.F.; Soares, M.A.; Zanuncio, J.C. 2019. Toxicity and cytopathology mediated by Bacillus thuringiensis in the midgut of Anticarsia gemmatalis (Lepidoptera: Noctuidae). Scientific Reports 9: 6667.

Castro, D.L.M.; García-Gómez, B.I.; Gómez, I.; Bravo, A.; Soberón, M. 2017. Identification of Bacillus thuringiensis Cry1AbMod binding-proteins from Spodoptera frugiperda. Peptides 98: 99-105.

Clapp, C.; Portt, L.; Khoury, C.; Sheibani, S.; Eid, R.; Greenwood, M.; Greenwood, M. D. 2012. Untangling the roles of antiapoptosis in regulating programmed cell death using humanized yeast cells. Frontiers in Oncology 2: 59.

Cunha, F.M.; Wanderley-Teixeira, V.; Teixeira, Á.A.C.; Santos, F.A.B.D.; Alves, L.C.; Caetano, F.H. 2013. Insect/Bt-cotton interactions: are immunological variables and hemocyte ultrastructure in Podisus nigrispinus (Hemiptera: Pentatomidae) affected? International Journal of Pest Management 59: 157-164.

Cunha, F.M.; Caetano, F.H.; Wanderley-Teixeira, V.; Torres, J.B.; Teixeira, Á.A.; Alves, L.C. 2012. Ultra-structure and histochemistry of digestive cells of Podisus nigrispinus (Hemiptera: Pentatomidae) fed with prey reared on bt-cotton. Micron 43: 245-250.

Daniel, A.G.; Peterson, E.J.; Farrell, N.P. 2014. The bioinorganic chemistry of apoptosis: potential inhibitory zinc binding sites in caspase-3. Angewandte Chemie 53: 4098-4101.

Devos, Y.; Schrijver, A.; Clercq, P.; Kiss, J.; Romeis, J. 2012. Btmaize event MON 88017 expressing Cry3Bb1 does not cause harm to non-target organisms. Transgenic Research 21: 11911214.

Dutra, C.C.; Koch, R.L.; Burkness, E.C.; Meissle, M.; Romeis, J.; Hutchison, W.D.; Fernandes, M.G. 2012. Harmonia axyridis (Coleoptera: Coccinellidae) exhibits no preference between Bt and non-Bt maize fed Spodoptera frugiperda (Lepidoptera: Noctuidae). PLoS One 7: e44867.
Farias, J.R.; Andow, D.A.; Horikoshi, R.J.; Sorgatto, R.J.; Fresia, P.; Santos, A.C.; Omoto, C. 2014. Field-evolved resistance to Cry1F maize by Spodoptera frugiperda (Lepidoptera: Noctuidae) in Brazil. Crop Protection 64: 150-158.

Gonçalves, C.A.P.; Botteon, P.T.L.; Alves, G.E.S.; Faleiros, R.R.; Leme, F.O.P.; Mendes, H.M.F.; Vasconcelos, A.C. 2013. Effect of nonsteroidal anti-inflammatory drugs on apoptosis of epidermal lamellar cells of equines with laminitis. Arquivo Brasileiro de Medicina Veterinária e Zootecnia 65: 1409-1418.

Gonçalves, T.S.; Soares, M.A.; Santos, C.A.; Santos, D.A.; Santos, J.B.; Barroso, G.A. 2016. Does the ingestion of isoxaflutole herbicide affect the midgut and salivary glands of Pentatomidae Predators? Planta Daninha 34: 125-132.

Greene, G.L.; Leppla, N.C.; Dickerson, W.A. 1976. Velvetbean caterpillar: a rearing procedure and artificial medium. Journal of Economic Entomology 69: 487-488.

Hilbeck, A.; Otto, M. 2015. Specificity and combinatorial effects of Bacillus thuringiensis Cry toxins in the context of GMO environmental risk assessment. Frontiers in Environmental Science 3: 71 .

Huang, F. 2020. Resistance of the fall armyworm, Spodoptera frugiperda, to transgenic Bacillus thuringiensis Cry $1 \mathrm{~F}$ corn in the America: lessons and implications for Bt corn IRM in China. Insect Science 1-16.

Ihara, T.; Yamamoto, T.; Sugamata, M.; Okumura, H.; Ueno, Y. 1998. The process of ultrastructural changes from nuclei to apoptotic body. Virchows Archiv 433: 443-447.

Javed, M.A.; Coutu, C.; Theilmann, D.A.; Erlandson, M.A.; Hegedus, D.D. 2019. Proteomics analysis of Trichoplusia ni midgut epithelial cell brush border membrane vesicles. Insect Science 26: 424-440.

Jesus, F.G.; Boiça, A.L.; Alves, G.C.; Zanuncio, J.C. 2014. Behavior, development, and predation of Podisus nigrispinus (Hemiptera: Pentatomidae) on Spodoptera frugiperda (Lepidoptera: Noctuidae) fed transgenic and conventional cotton cultivars. Annals of the Entomological Society of America 107: 601-606.

Lawo, N.C.; Wäckers, F.L.; Romeis, J. 2010. Characterizing indirect prey-quality mediated effects of a Bt crop on predatory larvae of the green lacewing, Chrysoperla carnea. Journal of Insect Physiology 56: 1702-1710.

Li, X.J.; Wu, M.F.; Ma, J.; Gao, B.Y.; Wu, Q.L.; Chen, A.D.; Chapman, J.W. 2019. Prediction of migratory routes of the invasive fall armyworm in eastern China using a trajectory analytical approach. Pest Management Science 76: 454-463.

Locke, M.; Collins, J.V. 1966. Sequestration of protein by the fat body of an insect. Nature 210: 552.

Locke, M.T.; Collins, J.V. 1968. Protein uptake into multivesicular bodies and storage granules in the fat body of an insect. The Journal of Cell Biology 36: 453-483.

Magalhães, G.O.; Vacari, A.M.; Bortoli, C.D.; Pomari, A.F.; Bortoli, S.D.; Polanczyk, R.A. 2015. Interactions between Btbioinsecticides and Podisus nigrispinus (Dallas) (Hemiptera: Pentatomidae), a predator of Plutella xylostella (L.) (Lepidoptera: Plutellidae). Neotropical Entomology 44: 521-527.

Marques, L.H.; Santos, A.C.; Castro, B.A.; Storer, N.P.; Babcock, J.M.; Lepping, M. D.; Fernandes, O.A. 2018. Impact of transgenic soybean expressing Cry1 Ac and Cry $1 \mathrm{~F}$ proteins on the non-target arthropod community associated with soybean in Brazil. PloS One 13: e0191567. 
Meissle, M.; Romeis, J. 2018. Transfer of Cry1Ac and Cry2Ab proteins from genetically engineered Bt cotton to herbivores and predators. Insect Science 25: 823-832.

Mendes, S.M.; Boregas, K.G.B.; Lopes, M.E.; Waquil, M.S.; Waquil, J.M. 2011. Fall armyworm responses to genetically modified corn expressing the Cry 1A toxin (b). Pesquisa Agropecuária Brasileira 46: 239-244 (in Portuguese, with abstract in English).

Mitsuhashi, W.; Miyamoto, K. 2020. Interaction of Bacillus thuringiensis Cry toxins and the insect midgut with a focus on the silkworm (Bombyx mori) midgut. Biocontrol Science and Technology 30: 68-84.

Moscardini, V.F.; Marques, L.H.; Santos, A.C.; Rossetto, J.; Silva, O.A.; Rampazzo, P. E.; Castro, B.A. 2020. Efficacy of Bacillus thuringiensis $(\mathrm{Bt})$ maize expressing Cry1F, Cry1A. 105, Cry2Ab2 and Vip3Aa20 proteins to manage the fall armyworm (Lepidoptera: Noctuidae) in Brazil. Crop Protection 137: 105269.

Neves, R.C.D.S.; Torres, J.B.; Zanuncio, J.C. 2010. Production and storage of mealworm beetle as prey for predatory stinkbug. Biocontrol Science and Technology 20: 1013-1025.

Oliveira, A.C.B.; Siqueira, H.Á.A.; Wanderley-Teixeira, V.; Teixeira, Á.A.C. 2016. Proteolytic activity characterization of Podisus nigrispinus gut contents and apparent lack of Cry1Ac toxin hydrolysis. Bulletin of Insectology 69: 143-148.

Oliveira, H.N.D.; Espindula, M.C.; Duarte, M.M.; Pereira, F.F.; Zanuncio, J.C. 2011. Development and reproduction of Podisus nigrispinus (Hemiptera: Pentatomidae) fed with Thyrinteina arnobia (Lepidoptera: Geometridae) reared on guava leaves. Brazilian Archives of Biology and Technology 54: 429-434.

Oliveira, H.N.D.; Pratissoli, D.; Pedruzzi, E.P.; Espindula, M.C. 2004. Development of the predator Podisus nigrispinus fed on Spodoptera frugiperda and Tenebrio molitor. Pesquisa Agropecuária Brasileira 39: 947-951.

Peluzio, R.J.E.; Castro, B.M.D.C.; Brügger, B.P.; Plata-Rueda, A.; Fernandes, F.L.; Santos, R.H.S.; Zanuncio, J.C. 2018. Does diet of prey affect life table parameters of the predator Podisus nigrispinus (Hemiptera: Pentatomidae)? Florida Entomologist 101: 40-43.

Pereira, G. 2014. Does Cry1Ab maize interfere in the biology and behavioural traits of Podisus nigrispinus? Bulletin of Insectology 67: 265-271.

Pizzamiglio, M.A. 1991. Ecology of Insect/Plant Interactions: Nutritional Ecology of Insects and their Implications for Pest Management. Manole, São Paulo, SP, Brazil (in Portuguese, with abstract in English).

Portt, L.; Norman, G.; Clapp, C.; Greenwood, M.; Greenwood, M.T. 2011. Anti-apoptosis and cell survival: a review. Biochimica et Biophysica Acta 1813: 238-259.

Prütz, G.; Dettner, K. 2004. Effect of Bt corn leaf suspension on food consumption by Chilo partellus and life history parameters of its parasitoid Cotesia flavipes under laboratory conditions. Entomologia Experimentalis et Applicata 111: 179-187.

Ramalho, F.S.; Azeredo, T.L.; Nascimento, A.R.B.; Fernandes, F.S.; Nascimento Júnior, J.L.; Malaquias, J.B.; Zanuncio, J.C. 2011. Feeding of fall armyworm, Spodoptera frugiperda, on Bt transgenic cotton and its isoline. Entomologia Experimentalis et Applicata 139: 207-214.
Razze, J.M.; Mason, C.E.; Pizzolato, T.D. 2011. Feeding behavior of neonate Ostrinia nubilalis (Lepidoptera: Crambidae) on $\mathrm{Cry} 1 \mathrm{Ab} \mathrm{Bt}$ corn: Implications for resistance management. Journal of Economic Entomology 104: 806-813.

Santana, A.G.; Ávila, C.J.; Oliveira, H.N.; Bellon, P.P.; SchlickSouza, E.C. 2017. Direct and Indirect Effect of Bt Cotton and No Bt Cotton on the Development and Reproduction of the Predator Podisus nigrispinus (Dallas, 1851) (Hemiptera: Pentatomidae). American Journal of Plant Sciences 8: 1438.

Santos, M.C.; Junqueira, M.R.; Sá, V.M.; Zanúncio, J.C.; Serrão, J.E. 2015. Effect of silicon on the morphology of the midgut and mandible of tomato leafminer Tuta absoluta (Lepidoptera: Gelechiidae) larvae. Invertebrate Survival Journal 12: 158-165.

Sikorowski, P.P.; Lawrence, A.M. 1997. Major diseases of Heliothis virescens and Helicoverpa zea in Mississippi Fields and Insectaries. Mississippi Agricultural \& Forestry Experiment Station, Mississippi State, MS, USA.

Souza, C.S.; Silveira, L.C.; Paula, D.P.; Andow, D.A.; Mendes, S.M. 2018. Transfer of Cry $1 \mathrm{~F}$ from Bt maize to eggs of resistant Spodoptera frugiperda. PloS One 13: e0203791.

Stewart, S.D.; Adamczyk, J.J.; Knighten, K.S.; Davis, F.M. 2001. Impact of Bt cottons expressing one or two insecticidal proteins of Bacillus thuringiensis Berliner on growth and survival of noctuid (Lepidoptera) larvae. Journal of Economic Entomology 94: 752-760.

Svobodovâ, Z.; Burkness, E.C.; Skoková Habuštová, O.; Hutchison, W.D. 2017a. Predator preference for Bt-Fed Spodoptera frugiperda (Lepidoptera: Noctuidae) prey: implications for insect resistance management in Bt maize seed blends. Journal of Economic Entomology 110: 1317-1325.

Svobodová, Z.; Shu, Y.; Habuštová, O.S.; Romeis, J.; Meissle, M. 2017b. Stacked Bt maize and arthropod predators: exposure to insecticidal Cry proteins and potential hazards. Proceedings of the Royal Society B: Biological Sciences 284: 20170440.

Telfer, W.H.; Kunkel, J.G. 1991. The function and evolution of insect storage hexamers. Annual Review of Entomology 36: 205-228.

Tian, J.C.; Wang, X.P.; Long, L.P.; Romeis, J.; Naranjo, S.E.; Hellmich, R.L.; Shelton, A.M. 2013. Bt crops producing Cry1Ac, Cry2Ab and Cry1F do not harm the green lacewing, Chrysoperla rufilabris. PloS One 8: e60125.

Tian, J.C.; Wang, X.P.; Long, L.P.; Romeis, J.; Naranjo, S.E.; Hellmich, R.L.; Shelton, A.M. 2014. Eliminating host-mediated effects demonstrates Bt maize producing Cry $1 \mathrm{~F}$ has no adverse effects on the parasitoid Cotesia marginiventris. Transgenic Research 23: 257-264.

Tojo, S.; Betchaku, T.; Ziccardi, V.J.; Wyatt, G.R. 1978. Fat body protein granules and storage proteins in the silkmoth, Hyalophora cecropia. The Journal of Cell Biology 78: 823-838.

Torres, J.B.; Barros, E.M.; Coelho, R.R.; Pimentel, R.M. 2010. Zoophytophagous pentatomids feeding on plants and implications for biological control. Arthropod-Plant Interactions 4: 219-227.

Vacari, A.M.; Otuka, A.K.; Bortoli, S.A. 2007. Development of Podisus nigrispinus (Dallas, 1851) (Hemiptera: Pentatomidae) fed with Diatraea saccharalis caterpillars (Fabricius, 1794) (Lepidoptera: Crambidae). Arquivos do Instituto Biológico 74: 259-265 (in Portuguese, with abstract in English). 
Vankosky, M.A.; Vanlaerhoven, S.L. 2015. Plant and prey quality interact to influence the foraging behaviour of an omnivorous insect, Dicyphus hesperus. Animal Behaviour 108: 109-116.

Vieira, E.R.D.; Silva, E.B.; Soares, M.A.; Assis Júnior, S.L.; Barroso, G.A.; Lemes, P. G. 2018. Lack of macronutrients in Eucalyptus urophylla ST Blake (Myrtaceae) seedlings affects feed and development of Podisus nigrispinus (Hemiptera: pentatomidae). Bioscience Journal 34: 42-48.

Yang, F.; Kerns, D.L.; Head, G.; Brown, S.; Huang, F. 2017. Susceptibility of Cry1F-maize resistant, heterozygous, and susceptible Spodoptera frugiperda to Bt proteins used in the transgenic cotton. Crop Protection 98: 128-135.

Yu, H.; Romeis, J.; Li, Y.; Li, X.; Wu, K. 2014. Acquisition of Cry1Ac protein by non-target arthropods in Bt soybean fields. PLoS One 9: e103973.

Zanuncio, J.C.; Molina-Rugama, A.J.; Serrao, J.; Pratissoli, D. 2001. Nymphal development and reproduction of Podisus nigrispinus (Heteroptera: Pentatomidae) fed with combinations of Tenebrio molitor (Coleoptera: Tenebrionidae) pupae and Musca domestica (Diptera: Muscidae) larvae. Biocontrol Science and Technology 11: 331-337.
Zanuncio, J.C.; Mourão, S.A.; Martínez, L.C.; Wilcken, C.F.; Ramalho, F.S.; Plata-Rueda, A.; Serrão, J.E. 2016. Toxic effects of the neem oil (Azadirachta indica) formulation on the stink bug predator, Podisus nigrispinus (Heteroptera: Pentatomidae). Scientific Reports 6: 30261.

Zanuncio, T.V.; Zanuncio, J.C.; Saavedra, J.L.; Lopes, E.D. 1996. Development of Podisus nigrispinus (Dallas) (Heteroptera: Pentatomidae) fed with Zophobas confusa Gebien (Coleoptera: Tenebrionidae) compared with two another alternative preys. Revista Brasileira de Zoologia 13: 159-164. 